\title{
Analysis of Renewable Energy Deployment in Colorado by 2030
}

\section{Technical Report} NREL/TP-550-42577

December 2007
R. Muren, Intern
C. Kutscher 


\section{Analysis of Renewable Energy Deployment in Colorado by 2030}

Technical Report NREL/TP-550-42577

December 2007

R. Muren, Intern

C. Kutscher

Prepared under Task No. 3418.4020

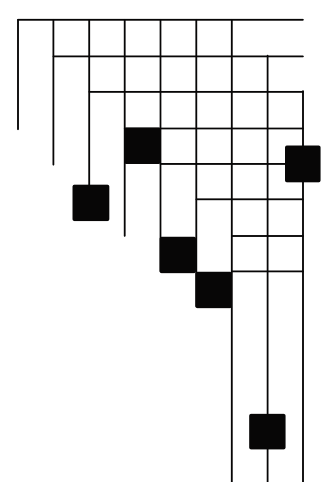




\section{NOTICE}

This report was prepared as an account of work sponsored by an agency of the United States government. Neither the United States government nor any agency thereof, nor any of their employees, makes any warranty, express or implied, or assumes any legal liability or responsibility for the accuracy, completeness, or usefulness of any information, apparatus, product, or process disclosed, or represents that its use would not infringe privately owned rights. Reference herein to any specific commercial product, process, or service by trade name, trademark, manufacturer, or otherwise does not necessarily constitute or imply its endorsement, recommendation, or favoring by the United States government or any agency thereof. The views and opinions of authors expressed herein do not necessarily state or reflect those of the United States government or any agency thereof.

Available electronically at http://www.osti.gov/bridge

Available for a processing fee to U.S. Department of Energy and its contractors, in paper, from:

U.S. Department of Energy

Office of Scientific and Technical Information

P.O. Box 62

Oak Ridge, TN 37831-0062

phone: 865.576 .8401

fax: 865.576 .5728

email: mailto:reports@adonis.osti.gov

Available for sale to the public, in paper, from:

U.S. Department of Commerce

National Technical Information Service

5285 Port Royal Road

Springfield, VA 22161

phone: 800.553.6847

fax: 703.605.6900

email: orders@ntis.fedworld.gov

online ordering: http://www.ntis.gov/ordering.htm 


\title{
Analysis of Renewable Energy Deployment in Colorado by 2030
}

\author{
Russell Muren \\ Office of Science, SULI Program \\ University of California, Berkeley \\ National Renewable Energy Laboratory \\ Golden, Colorado
}

August 10, 2007

\begin{abstract}
Prepared in partial fulfillment of the requirements of the Office of Science, U.S. Department of Energy Science Undergraduate Laboratory Internship (SULI) Program under the direction of Dr. Chuck Kutscher in the Center for Buildings and Thermal Systems at the National Renewable Energy Laboratory.
\end{abstract}

Participant:

Signature

Research Advisor:

Signature 


\begin{abstract}
Analysis of Renewable Energy Deployment in Colorado by 2030. Russell B. Muren (University of California Berkeley, Berkeley CA, 94720) Chuck Kutscher (National Renewable Energy Laboratory, 1617 Cole Boulevard, Golden CO, 80401).
\end{abstract}

Currently most utilities in the state of Colorado are subject to the $20 \%$ renewable portfolio standard (RPS) passed by voters in 2004 and expanded by the state legislature in 2007. However, because of bonuses and exemptions written into the law, the true required renewable energy penetration is only $12.3 \%$. This makes this law less then adequate for addressing climate change. This study aims to assess the real renewable energy and carbon impacts of the current RPS and investigates the benefits of increasing the RPS to true $20 \%$ and $30 \%$ values. To this end a user input-driven predictive Excel model was developed to find the proper technology spread, electrical outputs, and carbon reduction for each RPS. It was found that while all the RPS variants are technically feasible based on available renewable resources, only the 30\% RPS meets the carbon reductions that are thought necessary to avoid the worst impacts of climate change. Based on the results of this report the current RPS does not offer an effective avenue to reduce fossil fuel and carbon reduction. Furthermore, if the goal of the current Colorado legislature and administration is carbon reduction, a 30\% RPS is the most acceptable avenue. 
Table of Contents

Introduction $\quad 2$

Materials and methods $\quad 3$

$\begin{array}{ll}\text { Results } & 7\end{array}$

$\begin{array}{ll}\text { Conclusion } & 11\end{array}$

$\begin{array}{ll}\text { Acknowledgments } & 11\end{array}$

$\begin{array}{ll}\text { Literature Cited } & 12\end{array}$

$\begin{array}{ll}\text { Tables } & 14\end{array}$

$\begin{array}{ll}\text { Figures } & 15\end{array}$ 


\section{Introduction}

In 2004, voters in the state of Colorado passed Amendment 37, dictating that the state's utilities would be held to a Renewable Portfolio Standard (RPS) requiring the generation of $10 \%$ of their electricity from renewable energy (RE) sources by 2015 . As defined by the amendment, RE is electricity derived from "solar, wind, geothermal, biomass, new hydroelectricity with a nameplate rating of ten megawatts or less, and hydroelectricity in existence on January 1, 2005, with a nameplate rating of thirty megawatts or less"[1]. Spurred by the economic and environmental importance of RE, Colorado Governor Bill Ritter [2] signed House Bill 07-1281 in early 2007, expanding amendment 37 by requiring 20\% RE penetration by 2020 for investor-owned utilities and introducing new requirements for cooperative and municipal utilities.

There are many economic, environmental, societal and political goals of the Colorado RPS. Chief among them is the reduction of carbon emissions from the state's electricity producers. Many groups like the American Solar Energy Society (ASES) have developed reduction goals for carbon reduction over the next 50 years. ASES endorses a $60-80 \%$ reduction from year 2005 levels by 2050 as a way to sufficiently mitigate climate change [3]. To be on target for this level of reduction, the State of Colorado must reduce carbon emissions $20-27 \%$ from 2005 values by 2020. This report will serve as a guide and prediction of the possible RE deployment in the state of Colorado by the years 2011, 2015, and 2020. Furthermore, this study will try to assess the true carbon impact of the current RPS, a true $20 \%$ and a true $30 \%$ and assess their ability to reduce emissions sufficiently. Similar reports have already been produced by the Western Governors Association (WGA), the American Solar Energy Society (ASES), and a coalition of 
Department of Energy (DOE) labs [4, 3, 5]. However, these reports focus on the entire United States and are not specific enough to aid in the planning of state policy. This report will follow a similar approach with an in-depth focus on the State of Colorado.

\section{Materials and Methods}

Before any RE sources could be analyzed, a business as usual (BAU) case was created. The BAU was based on studies done by the Center for Climate Strategies predicting electrical and transportation energy consumption by the State of Colorado until the year 2020 [6]. These values were used to generate a growth model for the state's electrical supply broken down by the source of the electricity.

To fully understand the implications of the Colorado RPS, a breakdown analysis by utility was performed. Colorado's RPS counts each renewable megawatt (MW) as 1.25 MW and requires different levels of renewables based on the type and size of utility. These stipulations necessitated a utility-by-utility analysis of RPS compliance to determine the true renewables required to satisfy the law. The current market shares of each utility [7] were used to predict future market shares and consequently the RPS requirements for each utility. This data was then compiled to form a total required renewable deployment to satisfy the RPS. To explore the levels to which renewables might grow in Colorado and to investigate an RPS that would better reduce fossil fuel use while remaining economically valid, values were also obtained for a true $20 \%$ RPS and a true $30 \%$ RPS.

To fulfill the requirements of the RPS, each renewable source was analyzed separately to assess what it might reasonably contribute to the renewable portfolio. In all predictions an aggressive deployment strategy was assumed. In the cases of photovoltaics (PV), biomass, and geothermal capacity, a bottom-up modeling approach was used. Because 
these technologies have limited resource in Colorado or are constrained by other physical barriers they were analyzed without regard to the needed RE capacity. Conversely wind and concentrating solar power (CSP) were modeled from a top-down approach. Because the technical potential for wind and CSP is so large and they can both be installed in large quantities, their growth was modified based on the needed RE to fit the RPS.

To assess the CSP resources available to the state, general growth rates were taken from the WGA and ASES reports. This growth rate was then adjusted based on the needs of the RPS variant that was being studied. CSP values were adjusted in proportion to wind values to keep a significant mix of solar while maintaining a realistic balance between wind and CSP.

PV capacity was assessed assuming an aggressive new set of building codes that require maximum economical PV to be installed on new residential construction. Currently the PV industry has projected cost reductions through 2030 [4]. Using these projections and the Solar Advisor Model [9] the levelized cost of energy (LCOE) was calculated as a function of the projected cost of a residential PV system. When the LCOE dropped below the average cost of energy for the State of Colorado, it was assumed that new building codes would require all new construction to utilize roof-mounted PV. Roof capacity was estimated in a study by Navigant Consulting based on the US Census Bureau projection for the State of Colorado [10]. The growing PV capacity was extracted from this study to find the yearly installed capacity for the state assuming the aforementioned requirement for roof-mounted PV. 
Wind was modeled using a top-down approach. General growth rates were arrived at based on the WGA Wind Taskforce Report. These values were then adjusted to fit the needs of each RPS. In this way a total wind capacity for each year was determined.

To estimate the plausible geothermal capacity for the State of Colorado, the USGS was contacted [11]. Only hydrothermal geothermal was considered for this study because of the complexity of deeper enhanced geothermal systems resources. Development was then calculated based on federal leasing times and the total hydrothermal potential being completely developed by the year 2020 .

Biomass potential was evaluated based on two studies done by NREL and DOE. Gross potential values were taken from the study A Geographic Perspective on the Current Biomass Resource Availability in the United States [12]. These values gave us the upper limit of the potential biomass capacity, but not any sense of growth from year to year. To find estimated growth rates, the WGA Biomass Task Force Report was used to generate a supply curve for biomass deployment in the State of Colorado. This supply curve was then used in conjunction with the estimated price for electricity to find the yearly biomass deployment [13].

To convert from renewable capacity to renewable generation, capacity factors for each technology were used. A capacity factor is the ratio of average power output over a year to rated power output. For example, a capacity factor of 33\% for wind suggests that a 1 MW turbine would have an output of $0.33 \mathrm{MW}$ when averaged over all the hours of the year, generating $2.89 \mathrm{GWh}$ in one year. The capacity factors that were used are $33 \%, 41.3 \%$, $15.5 \%, 90 \%, 90 \%$ for wind, CSP, PV, biomass and geothermal, respectively [3] A table of capacity factors can be seen in Table 1 . 
Also added to the final mix of electrical production were aggressive best practice efficiency savings. These savings were calculated by Howard Geller at the Southwest Energy Efficiency Project (SWEEP) by studying the possible savings from demand side management, building codes, lamp standard and industrial options [14]. The savings were incoporated into the model.

New values of coal, natural gas, and imported capacity were calculated based on the new renewable development and aggressive best practice efficiency savings. These reduced values of coal and natural gas were assumed to fill in the capacity of the BAU that the renewables and efficiency did not fill. The mix of coal and natural gas was assumed to be three-to-one coal-to-gas as suggested by CCS [6].

Carbon emissions impact was found by calculating the displaced carbon emissions from each technology. To accurately gauge greenhouse gas emissions, a carbon equivalent value was used for the Colorado mix of electricity production. This value, 210 million metric tons of carbon-equivalent per gigawatt hour of electricity [6], represents the impact of all greenhouse gasses converted to an amount of pure carbon. By multiplying this value by the new capacity of each technology, the displaced carbon could be calculated. Finally summing the carbon displacement for each technology allowed a carbon reduction assessment of each RPS. This was done by comparing the carbon reduction from 2005 levels from each RPS with and without the help of best practices efficiency.

The next step in this study was to evaluate the cost of the development of each technology. This was done using projected industry costs. For each year of prediction a new capacity installation cost was calculated. The total lifetime cost of the yearly installation was calculated bringing the cost back to the present value for each individual year. This cost was 
then brought back to a 2005 dollar value and totaled for each technology. This value was then compared to the cost of building fossil fuel-based capacity to cover the same new electrical need. The difference is the total cost of the development of that renewable technology. All the costs for each technology could then be summed to find the total cost of the RPS. Simultaneously the cost of the efficiency savings was calculated using the same method. Because the cost of installing efficiency savings is generally cheaper then installing new capacity, the total cost of efficiency was negative, or in other words, installing energy efficiency measures resulted in a net economic savings rather than a cost. The total net economic cost could then be calculated by summing the costs of all technologies and efficiency.

Finally, the land area required for the predicted capacity of each technology was calculated. This was only done for the $30 \%$ RPS as it would require the most land area. Land area was calculated using conversion factors of 50,5 , and $50 \mathrm{MW} / \mathrm{km}^{2}$ for CSP, wind and $\mathrm{PV}$, respectively [15]. A value of .188 MW/thousand tonnes/yr was used to find the required tonnage of biomass to meet the $30 \%$ RPS [3].

\section{Results}

The application of the current RPS to the utility companies yielded a total $2020 \mathrm{RE}$ penetration of $12.3 \%$. Growth to this value was found and plotted in a wedge graph along with coal, natural gas, imported electricity, and hydroelectric to show the total capacity for the State of Colorado until the year 2020. Graphs for the current RPS, the true $20 \%$ RPS and the $30 \%$ RPS can be found in Figures 1, 2 and 3, respectively. 
Modeling each individual technology yielded a capacity growth and a maximum technical potential. Technical resource potential maps for the State of Colorado for wind, PV, CSP, biomass, and geothermal can be found in Figures 4, 5, 6, 7, and 8 respectively.

In all but the current RPS, wind had the most capacity in the year 2020, maxing out at over 4,000 MW with the 30\% RPS, as seen in Table 2. PV held the second largest wedge of capacity with a constant 1,847 MW throughout each RPS variant. Biomass and geothermal have smaller wedges of the total RE capacity with $266 \mathrm{MW}$ and $50 \mathrm{MW}$, respectively. CSP fills in the remainder in each RPS, maxing out at $670 \mathrm{MW}$ under the $30 \%$ RPS.

As seen in Table 3, under the current RPS the predicted 2020 renewable output of Colorado is $9,548 \mathrm{GWh}$, accounting for $16 \%$ of the total electricity production of the state. Wind comprises $40 \%$ of RE with $3,820 \mathrm{GWh}$ of generation. CSP comprises $8 \%$ of the RE total with $727 \mathrm{GWh}$ of generation. PV takes up $26 \%$ of the total RE with $2,508 \mathrm{GWh}$ of generation. Biomass accounts for $22 \%$ of the total RE, generating 2,099 GWh. Geothermal comprises the remaining $4 \%$ with $394 \mathrm{GWh}$. These values can be seen in Figures 4 and 5 respectively.

A true $20 \%$ RPS yields a predicted $2020 \mathrm{RE}$ output of $13,243 \mathrm{GWh}$, attaining a $22 \%$ penetration of total electricity production. Wind accounts for $52 \%$ of the RE with 6,924 GWh of production. CSP takes up $10 \%$ of the RE with $1318 \mathrm{GWh}$ of production. PV comprises $19 \%$ of the RE by generating 2,508 GWh. Biomass claims $16 \%$ with 2,099 GWh while geothermal fills the last $3 \%$ with $394 \mathrm{GWh}$ of production. The breakdown of the energy production under the true 20\% RPS is pictured in Figures 6 and 7. 
Under a true $30 \%$ RPS, RE grows to a predicted 2020 output of $20,195 \mathrm{GWh}$, comprising $34 \%$ of the total electrical production in the state. Wind produces $12,734 \mathrm{GWh}$ of that, claiming $63 \%$ of the RE generation. CSP holds $12 \%$ of the RE with $2,424 \mathrm{GWh}$ of production. PV comprises $12 \%$ of the RE with $2,508 \mathrm{GWh}$. Biomass accounts for $10 \%$ of the RE with 2,099 GWh. Geothermal again fills in the remaining 2\% with $394 \mathrm{GWh}$ of production. Representations of these values are shown in Figures 8 and 9.

Once the contributions from each technology were found, reductions in fossil fuel use could be calculated. Without efficiency savings fossil-fuel generation decreases by $16 \%,-7 \%$ and $6 \%$ from 2007 to 2020 under the current RPS, the true $20 \%$ and the true $30 \%$ respectively; with negative numbers corresponding to an increase in fossil fuel use. When best case aggressive efficiency savings are taken into account, these numbers shift down to a $10 \%, 15 \%$, and $25 \%$ decrease in fossil fuel use for the current, $20 \%$ and $30 \%$ RPS cases, respectively, as seen in Table 4.

Calculating the carbon displacement for each RPS without efficiency savings resulted in positive carbon reduction past 2005 levels for only the true $30 \%$ RPS. Moreover, none met the $20-27 \%$ goals for 2020 (consistent with the ASES goal of $60-80 \%$ reduction by 2050). These reduction values were $-15 \%,-8 \%$, and $4 \%$ the current, true $20 \%$, and true $30 \%$ RPS respectively, with negative reduction rates denoting carbon emissions growth by 2020 . With efficiency savings factored in, all three cases reduced carbon emissions past 2005 levels, but only the true $30 \%$ met the ASES goals. These reduction values were $12 \%, 18 \%$, and $31 \%$ for the current, true $20 \%$, and true $30 \%$ RPS respectively. Table 5 shows carbon savings from efficiency and RE and the resulting reduction in carbon emissions from 2005 levels. Wedge charts depicting the changing carbon emissions breakdown from 2005-2020 
can be found in Figures 10, 11, and 12 for the current, 20\%, and 30\% RPS cases, respectively.

Costing analysis resulted in a net economic savings for all but one of the RPS variants. Efficiency savings outweighed the cost of installing new renewable energy capacity in the current and true $20 \%$ RPS variants. The RE cost in the current RPS totaled $\$ 2.13$ billion, while the efficiency savings totaled $\$ 2.74$ billion yielding a net savings of $\$ 620$ million. For the true $20 \%$ RPS total RE cost was $\$ 2.45$ billion while efficiency stayed at $\$ 2.74$ billion in savings creating a net $\$ 300$ million savings. In the $30 \%$ RPS the $\$ 3.18$ billion cost of the RE surpassed the $\$ 2.74$ billion savings from efficiency creating a $\$ 440$ million deficit. A summary of the costs and net savings of each RPS case can be found in Table 6.

Calculating the land and roof area necessary to fulfill the $30 \%$ RPS showed that Colorado has significant resources. The land and roof area necessary to meet the $30 \%$ RPS CSP capacity is only 13 square $\mathrm{km}$, while the area needed to meet the $30 \%$ RPS wind capacity is only 881 square $\mathrm{km}$. (Note, however, that land containing wind turbines can still be used for farming.) The PV predicted in the 30\% RPS case requires 36 square $\mathrm{km}$ of roof space, only $9 \%$ of the residential roof space available. The biomass capacity predicted in the $30 \%$ RPS is met using the resources from only 10 Colorado counties using only $54.3 \%$ of the total resource available. Geothermal, under the 30\% RPS, takes advantage of the two hottest hydrothermal areas in Colorado. Resource maps with required area for CSP, wind, and biomass capacity can be found in Figures 13, 14 and 15, respectively. 


\section{Conclusions}

Although it is the easiest to establish, the current RPS is not sufficient to stop fossil growth or reduce carbon emissions. Coupled with aggressive best practice efficiency, the current RPS performance improves, but still does not meet the goals set out by ASES to adequately address climate change. Furthermore, the dependability of aggressive efficiency savings is questionable because they rely on separate public policy that may or may not become reality. Consequently, the modeling done in this study suggests that the current RPS is inadequate for mitigation of carbon emissions. Furthermore, the modeling suggests that a true $20 \%$ RPS may not be sufficient to truly curb global climate change. The only variant studied that showed adequate carbon reductions by 2020 was the true $30 \%$ RPS. The modeling also suggests that in any of the RPS variants wind will dominate the renewable mix, although substantial portions being assumed by CSP, PV and biomass will still be present. Finally the modeling strongly shows that Colorado has a mix of renewables that can be combined to reach RPS variants that exceed the current RPS.

\section{Acknowledgements}

I would not have been able to achieve the work that I did in the ten weeks that I was here if it were not for the help of many people from all around NREL and the Colorado renewable energy community. Thanks to everyone who helped me understand the technology, modeling, politics, and assumptions that go along with renewable energy predictions.

Special thanks to:

Chuck Kutscher - NREL (Mentor)

Nate Blair - NREL (Wind, CSP)

Donna Heimiller - NREL (Wind, CSP)

Anelia Milbrandt - NREL (Biomass)

Paul Denholm - NREL (PV)

Matt Sares - USGS CO (Geothermal)

Howard Geller - SWEEP (Efficiency)

The Office of Science

Center for Buildings and Thermal Systems, NREL 


\section{Literature Cited}

1. REPRESENTATIVES Pommer and Witwer, Benefield, Borodkin, Buescher, Butcher, Casso, Cerbo, Fischer, Frangas, Gagliardi, Garcia, Gibbs, Green, Hicks, Jahn, Kefalas, Kerr A., Kerr J., Labuda, Levy, Looper, Madden, Marostica, Marshall, Massey, McFadyen, McGihon, McKinley, Merrifield, Peniston, Primavera, Rice, Riesberg, Roberts, Solano, Summers, Todd, Vaad, Carroll M., Carroll T., Hodge, Romanoff, Sonnenberg, Soper, Weissmann, Gallegos, Liston, Stafford, and White; also SENATORS Schwartz, Bacon, Boyd, Fitz-Gerald, Gordon, Groff, Johnson, Keller, Kester, Morse, Romer, Shaffer, Tapia, Tochtrop, Tupa, Veiga, Williams, and Windels, House Bill 07-1281, Denver: Congress, 2007.

2. B. Ritter, "The Colorado Promise", Denver 2006.

3. C. Kutscher, Tackling Climate Change in the U.S., Boulder: ASES, 2007

4. W. Keese, W. Real, Clean Energy, a Strong Economy and a Healthy Environment, Denver: WGA, 2006

5. M. Levine, J. Koomey, L. Price, N. Martin, Scenarios of U.S. Carbon Reductions: Potential Impacts of Energy-Efficient and Low-Carbon Technologies by 2010 and Beyond, Oak Ridge: Oak Ridge National Laboratory, 1997

6. R. Strait, S. Rose, A. Bailie, H. Lindquist, A. Jamison, "Colorado Greenhouse Gas Inventory and Reference Case Projections 1990-202”, Harrisburg: Center for Climate Strategies, 2007

7. "Public Utilities Commission Home Page," [Online document], 2007, Available HTTP: http://www.dora.state.co.us/PUC/ 
8. Solar Advisory Model was developed by NREL in 2006

9. M. Chaudhari, L. Frantzis, T. Hoff, PV Grid Connected Market Potential in 2010 under a Cost Breakthrough Scenario, San Francisco: Energy Foundation, 2004

10. Phone interview with Matt Sares, June $19^{\text {th }} 2007$ regarding hydrothermal power

11. A. Milbrandt, A Geographic Perspective on the Current Biomass Resource Availability in the United States, Golden: NREL, 2005

12. WGA Biomass Task Force, A Biomass Task-Force Report, Denver: WGA, 2006

13. Conversation with Howard Geller, Southwest Energy Efficiency Project (SWEEP), 2260 Baseline Rd, 07/02/2007

14. E-mail correspondence with Nate Blair, NREL, 1617 Cole Blvd. 08/07/07 
Tables:

Table 1: Capacity factors for each technology

\begin{tabular}{|l|r|c|c|c|r|}
\hline & \multicolumn{1}{|c|}{ Wind } & \multicolumn{1}{l|}{ CSP } & PV & Biomass & Geothermal \\
\hline Capacity Factor & $33 \%$ & $41 \%$ & $15 \%$ & $90 \%$ & $90 \%$ \\
\hline Source & 3 (class 4+) & 3 & 3 & 3 & 3 \\
\hline
\end{tabular}

Table 2: 2020 RE capacity by technology under current, $20 \%$ and $30 \%$ RPS

\begin{tabular}{|c|c|c|c|c|c|c|c|c|c|c|c|}
\hline Variant & $\begin{array}{l}\text { Wind } \\
\text { (MW) }\end{array}$ & $\begin{array}{l}\% \text { of } \\
\text { RE }\end{array}$ & $\begin{array}{l}\text { CSP } \\
(\mathrm{MW}) \\
\end{array}$ & $\begin{array}{c}\% \text { of } \\
\mathrm{RE}\end{array}$ & $\begin{array}{l}\text { PV } \\
\text { (MW) }\end{array}$ & $\begin{array}{l}\% \text { of } \\
\mathrm{RE}\end{array}$ & $\begin{array}{l}\text { Biomass } \\
\text { (MW) }\end{array}$ & $\begin{array}{c}\% \text { of } \\
\mathrm{RE}\end{array}$ & $\begin{array}{l}\text { Geothermal } \\
\text { (MW) }\end{array}$ & $\begin{array}{c}\% \text { of } \\
\mathrm{RE}\end{array}$ & $\begin{array}{l}\text { Total RE } \\
\text { Capacity } \\
\end{array}$ \\
\hline Current RPS & 1321 & $36 \%$ & 201 & $5 \%$ & 1847 & $50 \%$ & 266 & $7 \%$ & 50 & $1 \%$ & 3686 \\
\hline True $20 \%$ & 2395 & $49 \%$ & 364 & $7 \%$ & 1847 & $38 \%$ & 266 & $5 \%$ & 50 & $1 \%$ & 4923 \\
\hline True $30 \%$ & 4405 & $61 \%$ & 670 & $9 \%$ & 1847 & $26 \%$ & 266 & $4 \%$ & 50 & $1 \%$ & 7238 \\
\hline
\end{tabular}

Table 3: 2020 RE production by technology under current, 20\%, and $30 \%$ RPS

\begin{tabular}{|c|c|c|c|c|c|c|c|c|c|c|c|}
\hline Variant & $\begin{array}{l}\text { Wind } \\
(\mathrm{GWh})\end{array}$ & $\begin{array}{c}\% \text { of } \\
\text { RE }\end{array}$ & $\begin{array}{l}\mathrm{CSP} \\
(\mathrm{GWh}) \\
\end{array}$ & $\begin{array}{c}\% \text { of } \\
\text { RE }\end{array}$ & $\begin{array}{l}\text { PV } \\
(\mathrm{GWh})\end{array}$ & $\begin{array}{l}\% \text { of } \\
\text { RE }\end{array}$ & $\begin{array}{l}\text { Biomass } \\
(\mathrm{GWh})\end{array}$ & $\begin{array}{c}\% \text { of } \\
\text { RE }\end{array}$ & $\begin{array}{l}\text { Geothermal } \\
(\mathrm{GWh})\end{array}$ & $\begin{array}{c}\% \text { of } \\
\text { RE }\end{array}$ & $\begin{array}{l}\text { Total RE } \\
\text { Generation }\end{array}$ \\
\hline $\begin{array}{l}\text { Current } \\
\text { RPS }\end{array}$ & 3820.07 & $40 \%$ & 727 & $8 \%$ & 2508 & $26 \%$ & 2099 & $22 \%$ & 394 & $4 \%$ & 9548 \\
\hline $\begin{array}{l}\text { True } \\
20 \% \\
\end{array}$ & 6924 & $52 \%$ & 1318 & $10 \%$ & 2508 & $19 \%$ & 2099 & $16 \%$ & 394 & $3 \%$ & 13243 \\
\hline $\begin{array}{l}\text { True } \\
30 \%\end{array}$ & 12734 & $63 \%$ & 2424 & $12 \%$ & 2508 & $12 \%$ & 2099 & $10 \%$ & 394 & $2 \%$ & 20159 \\
\hline
\end{tabular}

Table 4: Impact on fossil fuel use from RPS alone and with aggressive efficiency savings

\begin{tabular}{|l|c|c|}
\hline \multicolumn{1}{|c|}{ Variant } & $\begin{array}{c}2007-2020 \text { Fossil Fuel } \\
\text { Growth Sans-Efficiency }\end{array}$ & $\begin{array}{c}207-2020 \text { Fossil Fuel } \\
\text { Growth with Efficiency }\end{array}$ \\
\hline Current RPS & $16 \%$ & $-10 \%$ \\
\hline True $20 \%$ & $7 \%$ & $-15 \%$ \\
\hline True $30 \%$ & $-6 \%$ & $-25 \%$ \\
\hline
\end{tabular}

Table 5: Carbon impacts of RPS variants

\begin{tabular}{|c|l|r|r|}
\hline & & Reduction (MmtC) & \% reductions of 2005 \\
\hline \multirow{2}{*}{$\begin{array}{c}\text { Current } \\
\text { RPS }\end{array}$} & Reduction with efficiency & 5.1 & $12 \%$ \\
\cline { 2 - 4 } & Reduction sans-efficiency & 2.0 & $-15 \%$ \\
\hline \multirow{3}{*}{ True 20\% } & Reduction with efficiency & 5.9 & $18 \%$ \\
\cline { 2 - 4 } & Reduction sans-efficiency & 2.8 & $-8 \%$ \\
\hline \multirow{3}{*}{ True 30\% } & Reduction with efficiency & 7.3 & $31 \%$ \\
\cline { 2 - 4 } & Reduction sans-efficiency & 4.2 & $4 \%$ \\
\hline
\end{tabular}

Table 6: Total net cost of RE capacity and efficiency

\begin{tabular}{|l|c|c|c|}
\hline \multicolumn{1}{|c|}{ Variant } & $\begin{array}{c}\text { cost of } \\
\text { RE }(\mathrm{B} \$)\end{array}$ & $\begin{array}{c}\text { cost of Efficiency } \\
(\mathrm{B} \$)\end{array}$ & $\begin{array}{c}\text { Total cost } \\
(\mathrm{B} \$)\end{array}$ \\
\hline Current RPS & 2.13 & -2.74 & -0.62 \\
\hline True $20 \%$ & 2.45 & -2.74 & -0.30 \\
\hline True $30 \%$ & 3.18 & -2.74 & 0.44 \\
\hline
\end{tabular}




\section{Figures:}

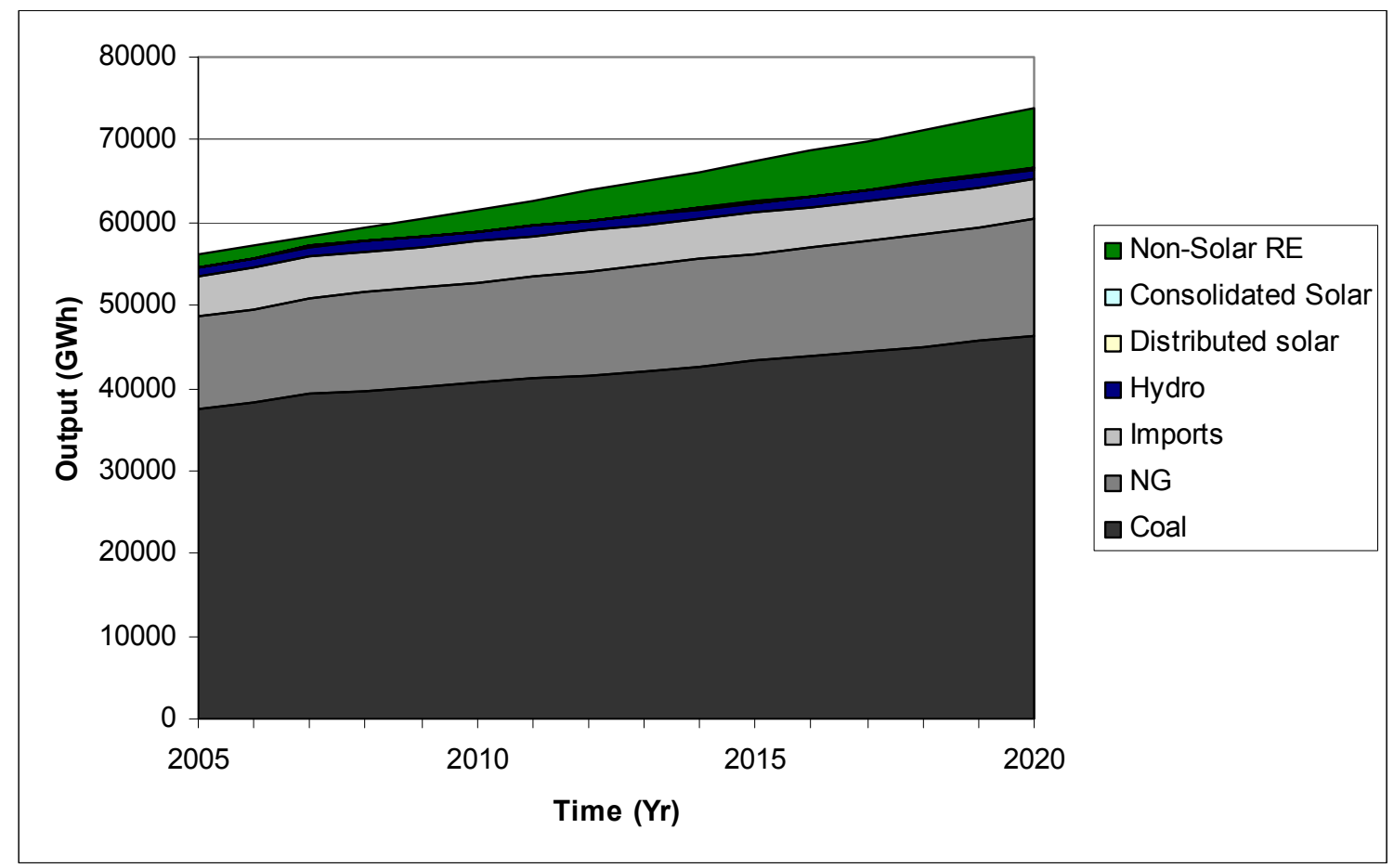

Figure 1: Resulting electrical capacity based on the current RPS

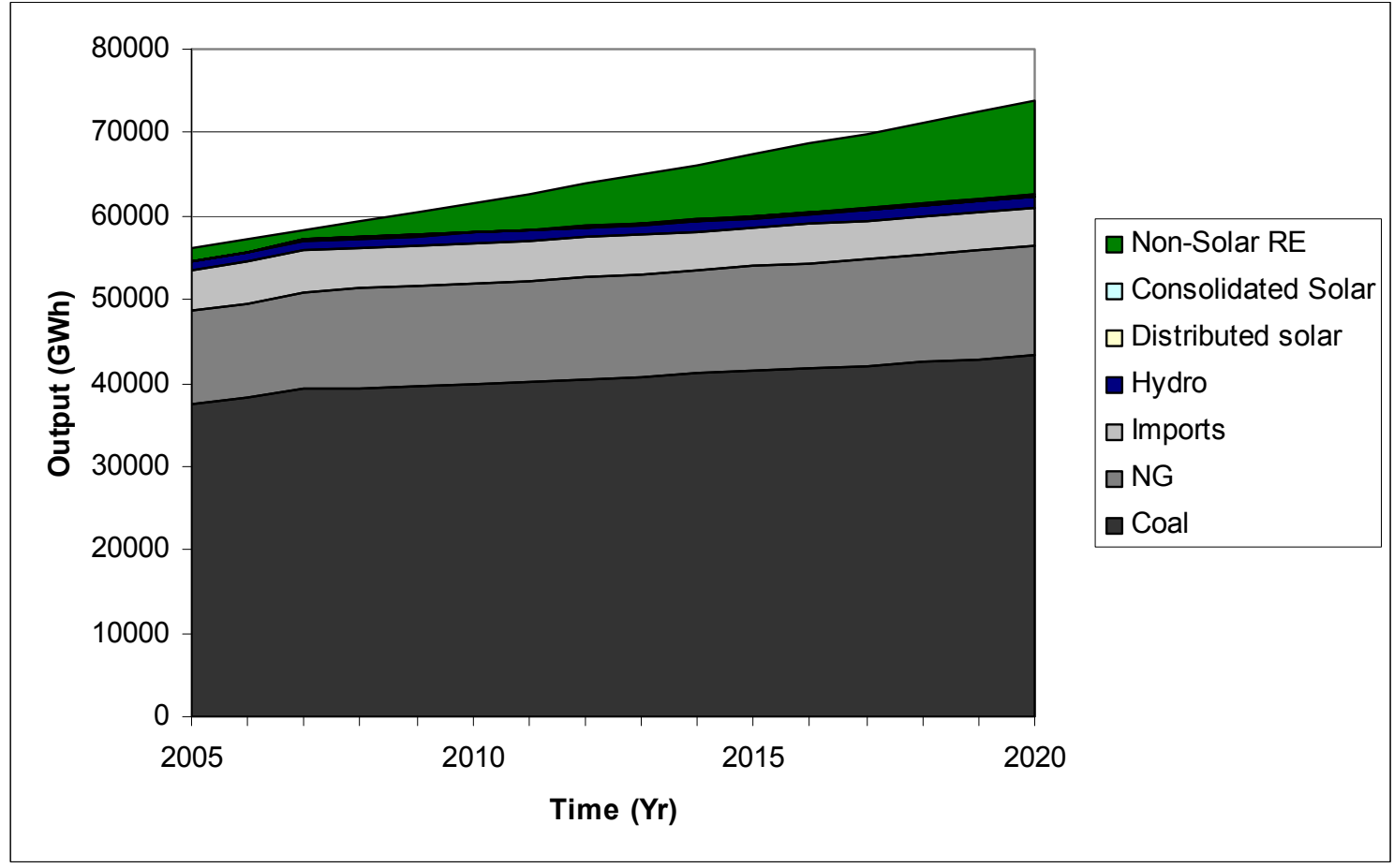

Figure 2: Resulting electrical capacity based on a true $20 \%$ RPS 


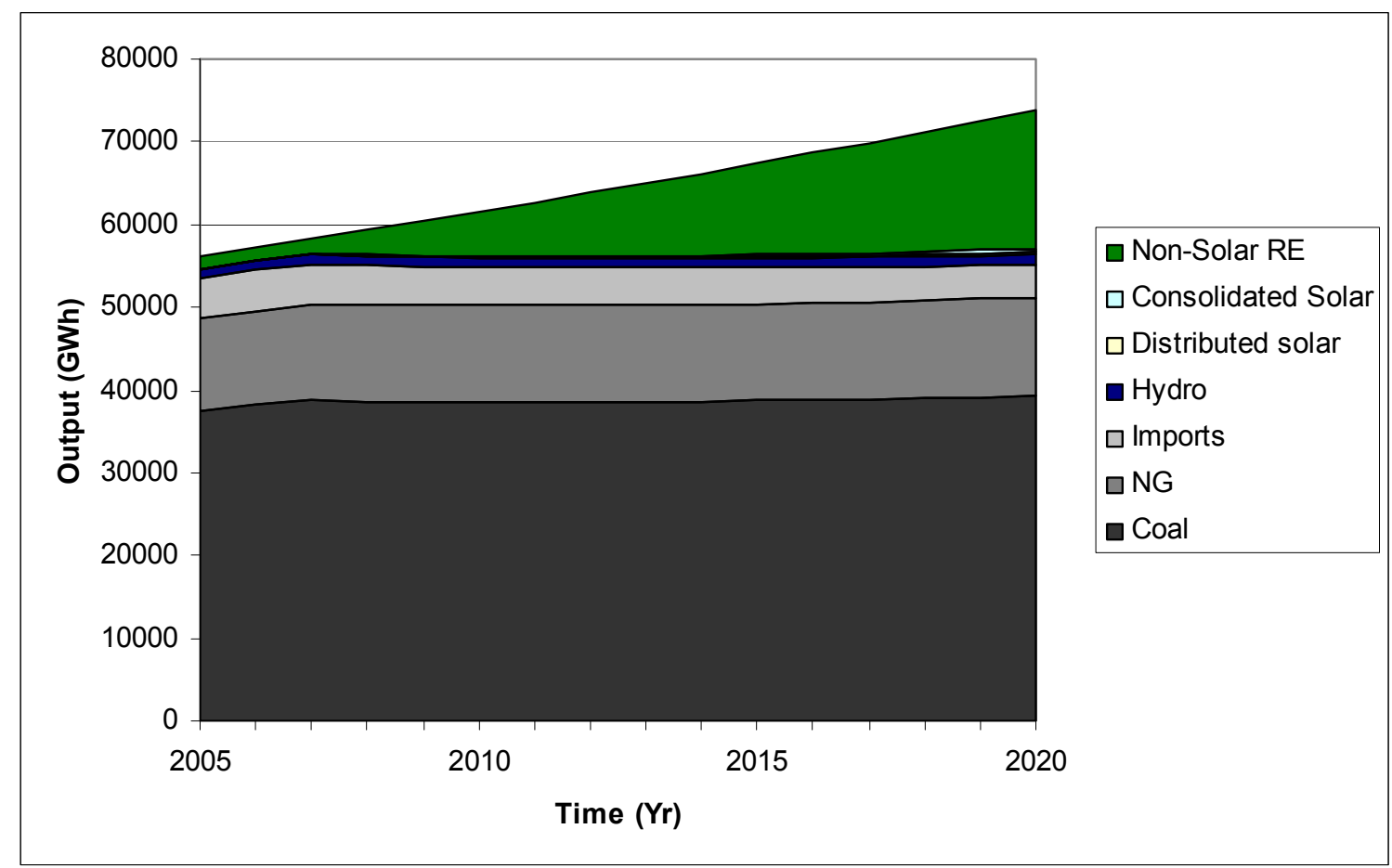

Figure 3: Resulting electrical capacity based on a true $30 \%$ RPS

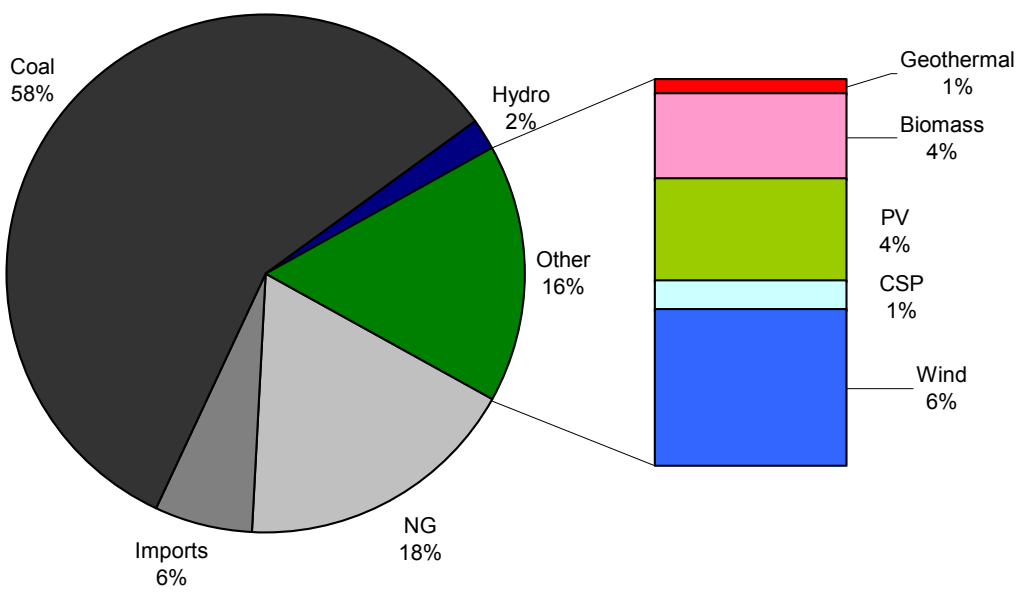

$\square N G$

$\square$ Imports

acoal

$\square$ Geothermal

$\square$ Biomass

$\square P V$

$\square \mathrm{CSP}$

$\square$ Wind

- Hydro

Figure 4: 2020 breakdown of energy production under the current RPS 


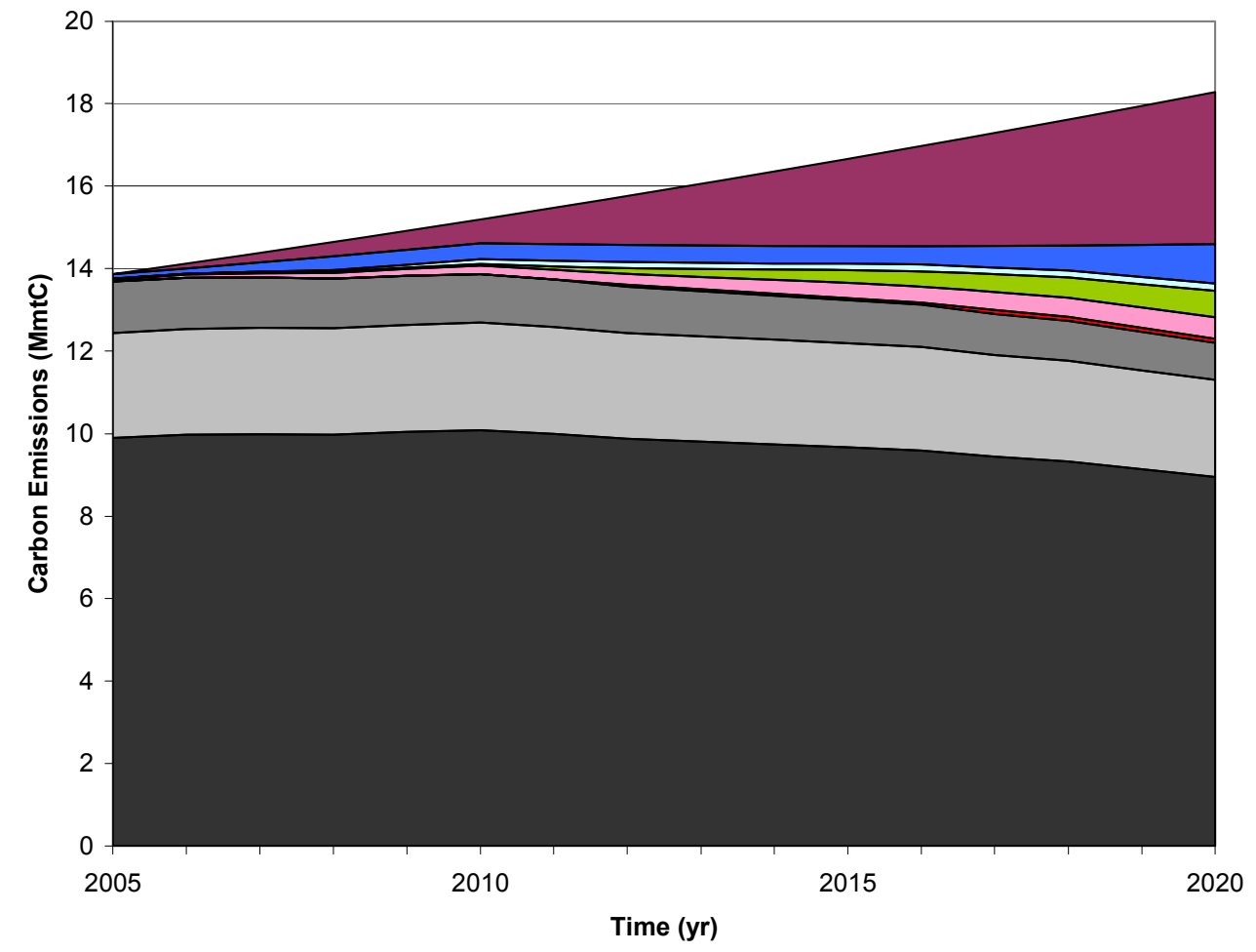

DEfficiency

$\square$ Wind

$\square$ CSP

$\square \mathrm{PV}$

$\square$ Biomass

$\square$ Geothermal

almports

$\square$ NG

acoal

Figure 5: Breakdown of electrical production growth under the current RPS

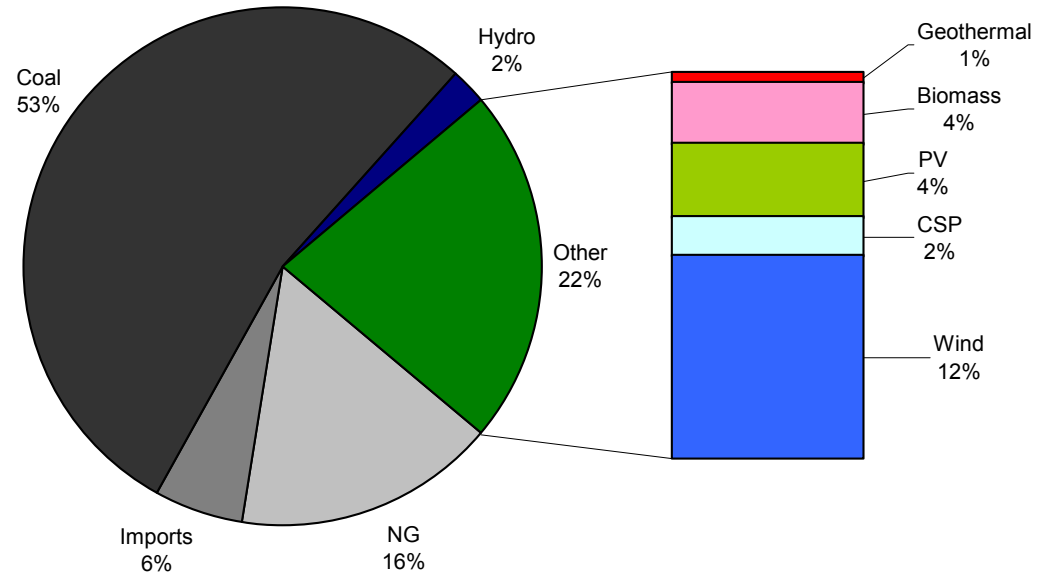

Figure 6: 2020 breakdown of energy production under a true 20\% RPS 


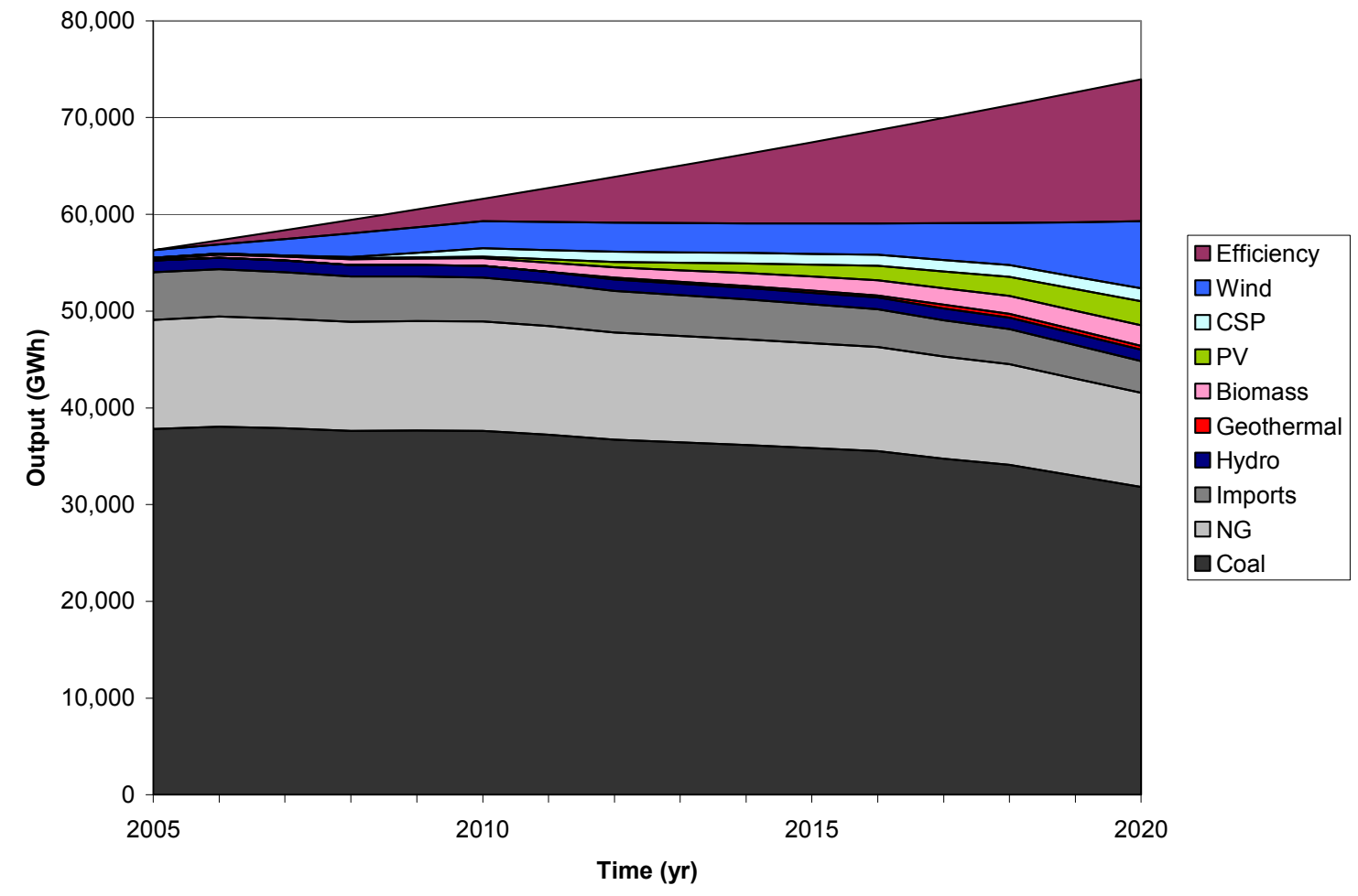

Figure 7: Breakdown of electrical production growth under a true $20 \%$ RPS

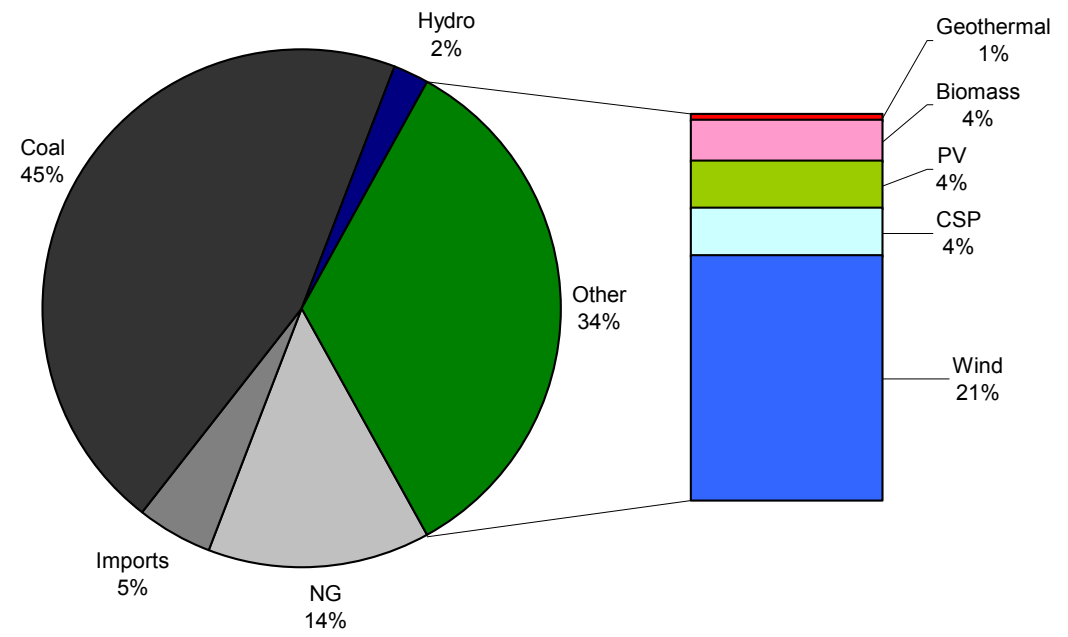

\begin{tabular}{|l|}
\hline$\square N G$ \\
$\square$ Imports \\
$\square$ Coal \\
$\square$ Geothermal \\
$\square$ Biomass \\
$\square P V$ \\
$\square$ CSP \\
$\square$ Wind \\
$\square$ Hydro \\
\hline
\end{tabular}

Figure 8: 2020 breakdown of energy production under a true 30\% RPS 


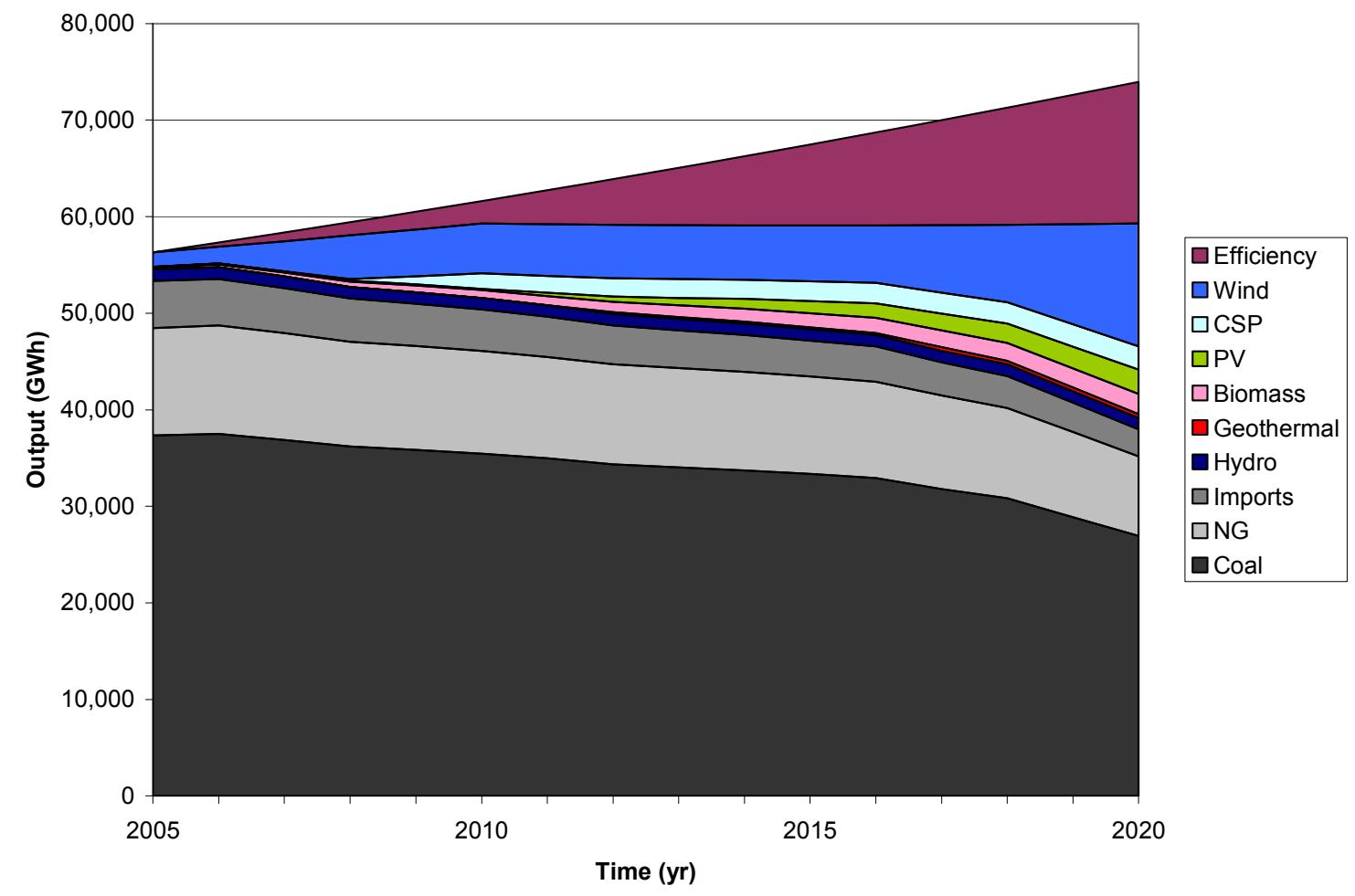

Figure 9: Breakdown of electrical production growth under a true $30 \%$ RPS

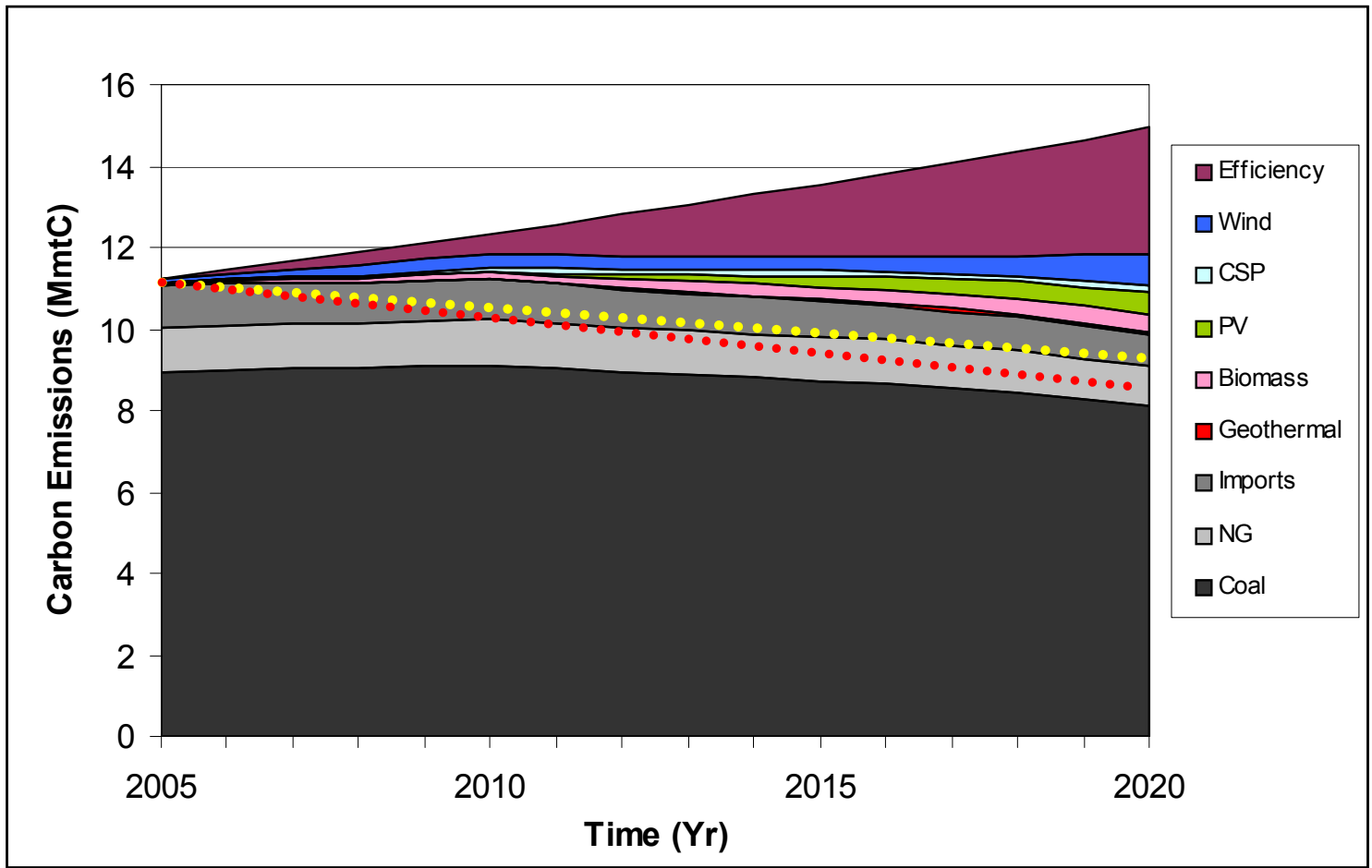

Figure 10: Growth of carbon displacement through RE and efficiency by 2020 under the current RPS with ASES 20\%-27\% carbon reduction goals 


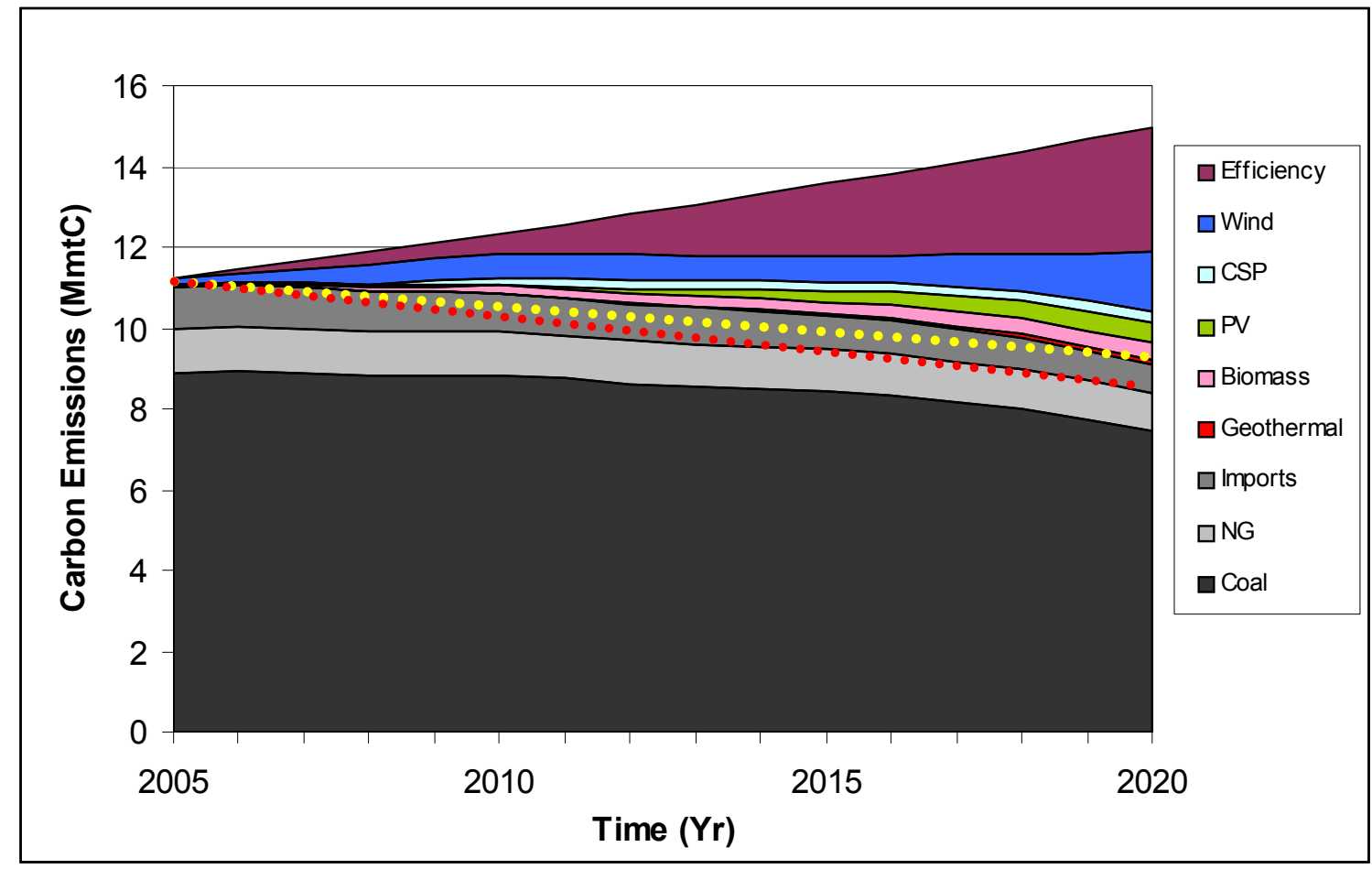

Figure 11: Growth of carbon displacement through RE and efficiency by 2020 under a true $20 \%$ RPS with ASES 20\%-27\% carbon reduction goals

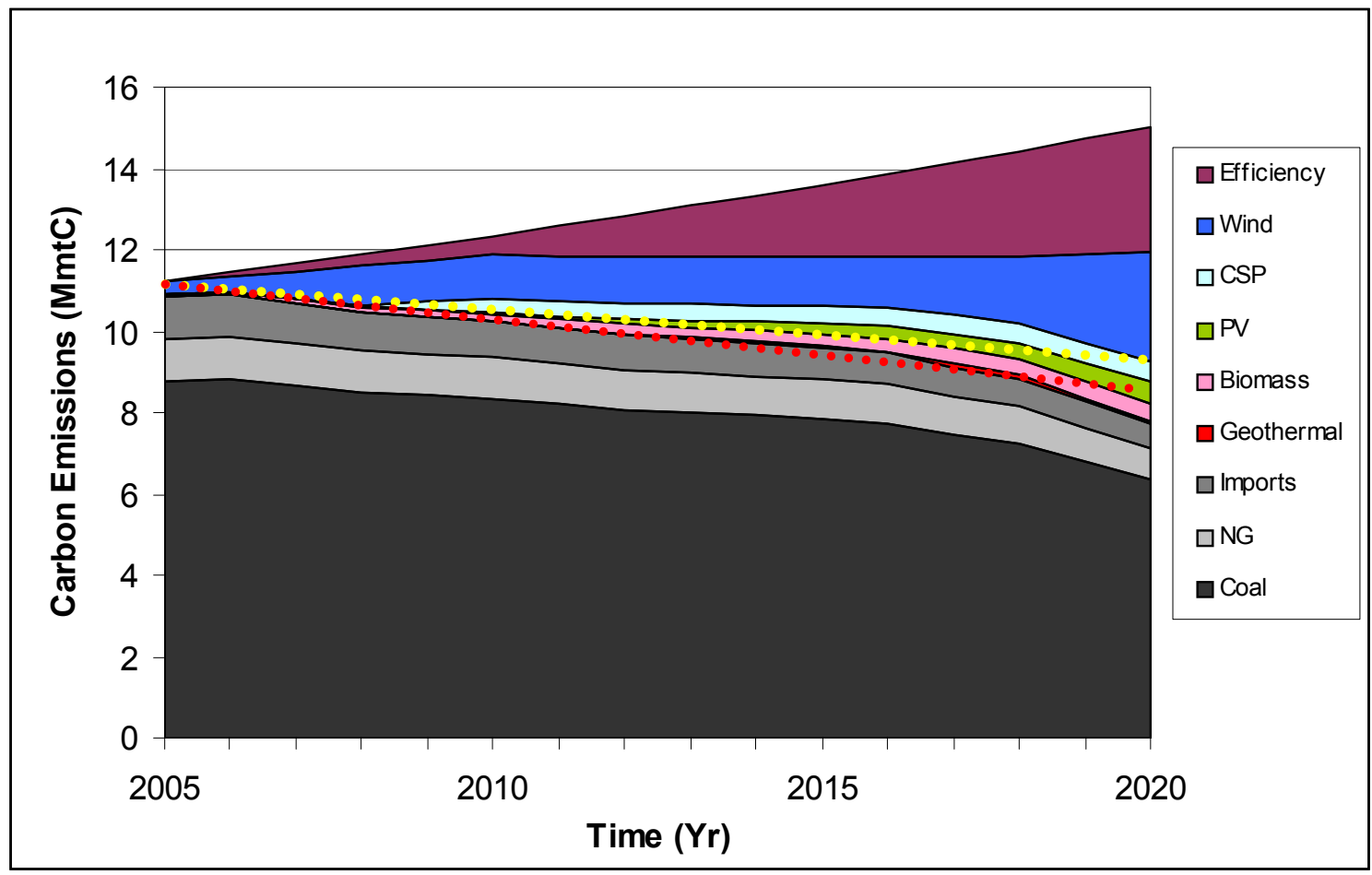

Figure 12: Growth of carbon displacement through RE and efficiency by 2020 under a true $30 \%$ RPS with ASES 20\%-27\% carbon reduction goals 


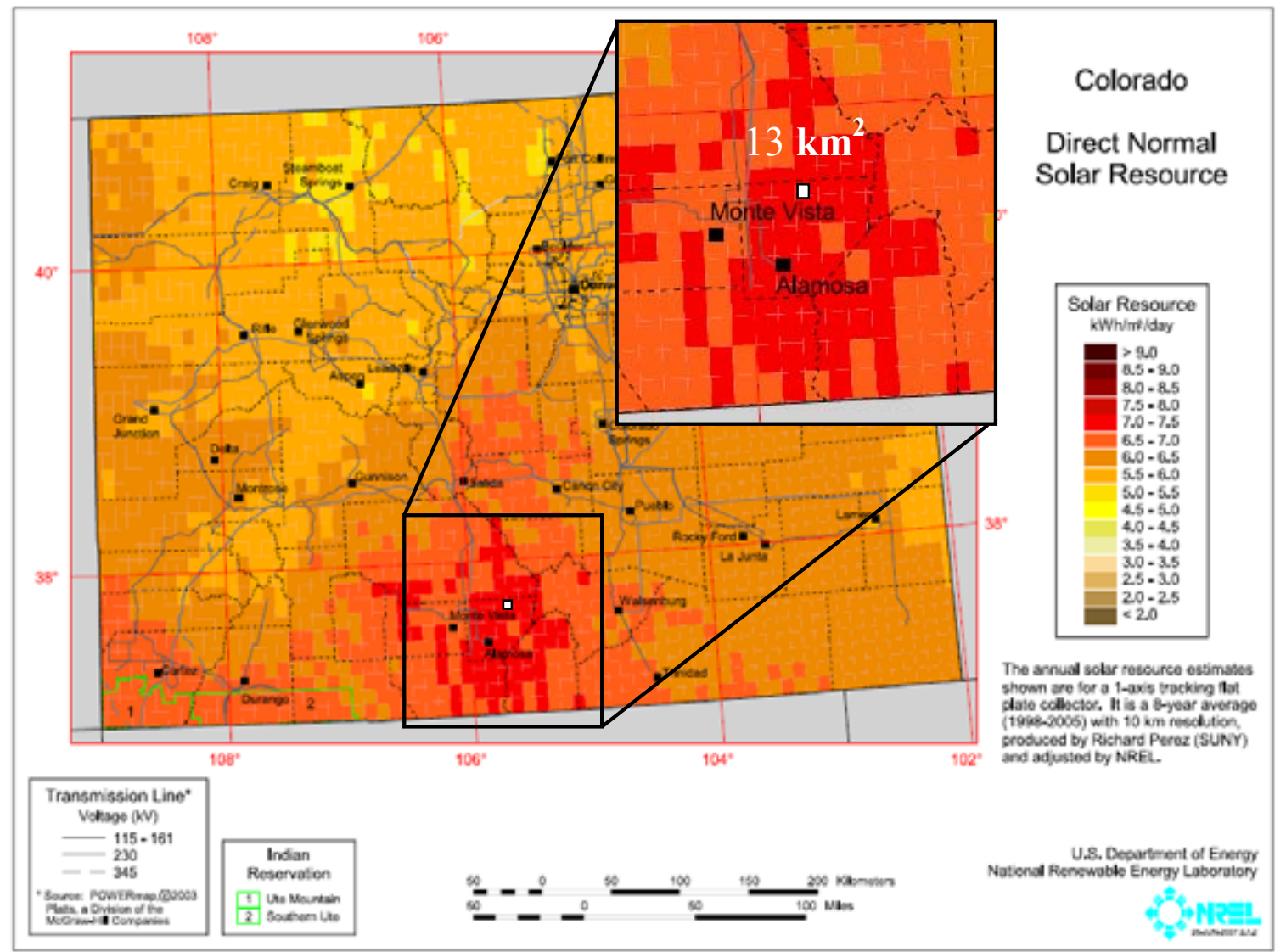

Figure 13: CSP resource and location in Colorado with projected necessary area of deployment

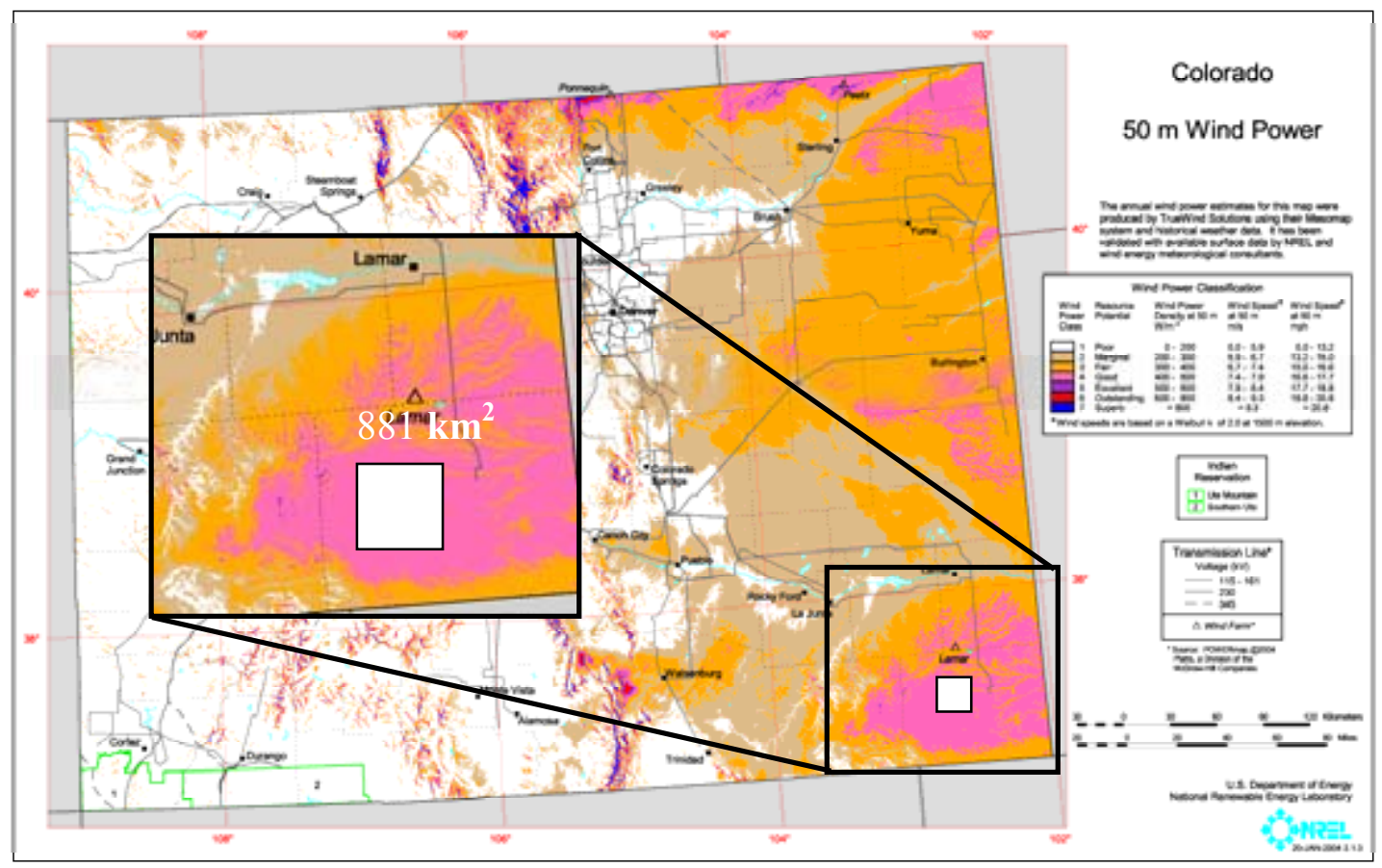

Figure 14: Wind resource and location in Colorado with projected necessary area of deployment 


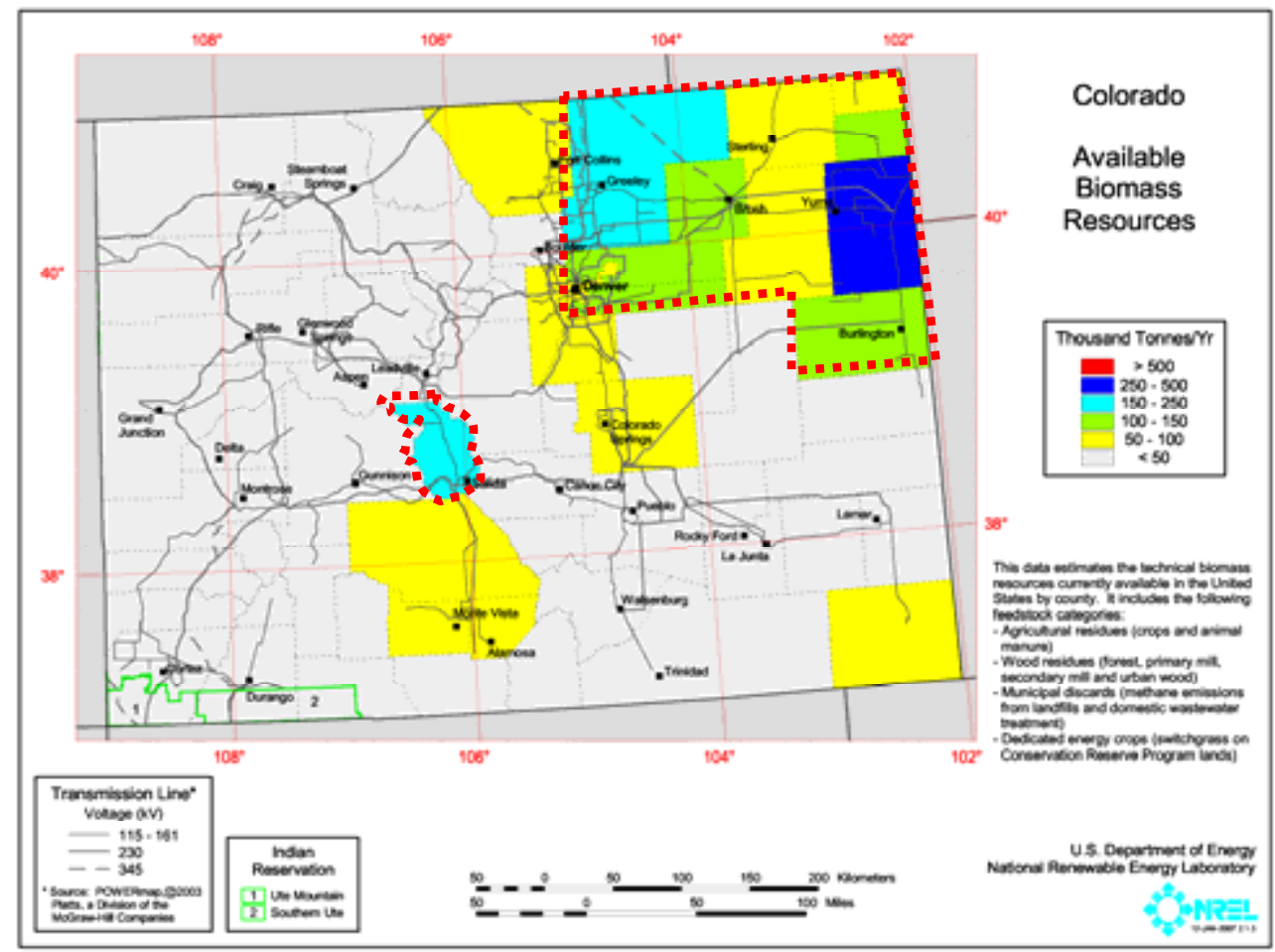

Figure 15: Biomass resource and location in Colorado with necessary counties highlighted 


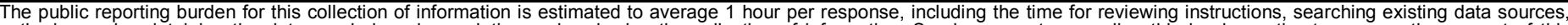

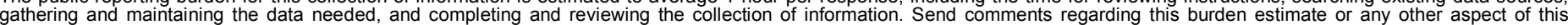

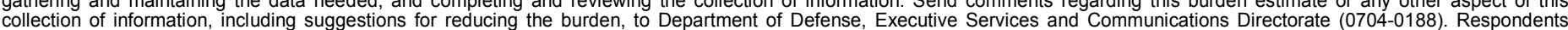

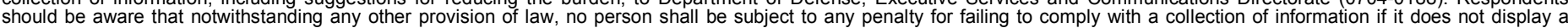

should be aware that notwithstanding

PLEASE DO NOT RETURN YOUR FORM TO THE ABOVE ORGANIZATION.

\begin{tabular}{l|l|l|l} 
1. REPORT DATE $(D D-M M-Y Y Y Y)$ & 2. & REPORT TYPE & 3. DATES COVERED (FrOm - TO)
\end{tabular}

December 2007

Technical Report

4. TITLE AND SUBTITLE

Analysis of Renewable Energy Deployment in Colorado by 2030

5a. CONTRACT NUMBER

DE-AC36-99-GO10337

5b. GRANT NUMBER

5c. PROGRAM ELEMENT NUMBER

6. AUTHOR(S)

R. Muren and C. Kutscher

5d. PROJECT NUMBER

NREL/TP-550-42577

5e. TASK NUMBER

3418.4020

5f. WORK UNIT NUMBER
7. PERFORMING ORGANIZATION NAME(S) AND ADDRESS(ES)

National Renewable Energy Laboratory

1617 Cole Blvd.

Golden, CO 80401-3393

9. SPONSORING/MONITORING AGENCY NAME(S) AND ADDRESS(ES)
8. PERFORMING ORGANIZATION REPORT NUMBER

NREL/TP-550-42577

12. DISTRIBUTION AVAILABILITY STATEMENT

National Technical Information Service

U.S. Department of Commerce

5285 Port Royal Road

Springfield, VA 22161

\section{SUPPLEMENTARY NOTES}

\section{ABSTRACT (Maximum 200 Words)}

Currently, most utilities in the state of Colorado are subject to the $20 \%$ renewable portfolio standard (RPS) passed by voters in 2004 and expanded by the state legislature in 2007 . However, because of bonuses and exemptions written into the law, the true required renewable energy penetration is only $12.3 \%$, making the law less then adequate for addressing climate change. The study aims to assess the real renewable energy and carbon impacts of the current RPS and investigates the benefits of increasing the RPS to true $20 \%$ and $30 \%$ values. A user input-driven predictive Excel model was developed to find the proper technology spread, electrical outputs, and carbon reduction for each RPS. It was found that while all the RPS variants are technically feasible based on available renewable resources, only the $30 \%$ RPS meets the carbon reductions that are thought necessary to avoid the worst impacts of climate change. The report then comments on the results and what RPS percentage will be the most acceptable avenue.

15. SUBJECT TERMS

NREL; renewable portfolio standards; RPS investigation; renewable energy deployment; Colorado; Russell Muren; Chuck Kutscher

\begin{tabular}{|c|c|c|c|c|}
\hline \multicolumn{3}{|c|}{ 16. SECURITY CLASSIFICATION OF: } & \multirow{2}{*}{$\begin{array}{l}\text { 17. LIMITATION } \\
\text { OF ABSTRACT } \\
\text { UL }\end{array}$} & \multirow{2}{*}{$\begin{array}{ll}\text { 18. } & \text { NUMBER } \\
\text { OF PAGES }\end{array}$} \\
\hline $\begin{array}{l}\text { a. REPORT } \\
\text { Unclassified }\end{array}$ & $\begin{array}{l}\text { b. ABSTRACT } \\
\text { Unclassified }\end{array}$ & $\begin{array}{l}\text { c. THIS PAGE } \\
\text { Unclassified }\end{array}$ & & \\
\hline
\end{tabular}

19a. NAME OF RESPONSIBLE PERSON

19b. TELEPHONE NUMBER (Include area code) 